\title{
Effects of neonatal hypoxia on mice behavior and oxidative stress
} parameters

\author{
Letvcia de Campos Brand $\gamma 0^{* 1}$, Karina Camasmie Abe ${ }^{1}$, Sergio Tufik ${ }^{1}$ and \\ Vßnia D'Almeida ${ }^{1,2}$
} \author{
of Syo Paulo, Syo Paulo, Brazil \\ * Corresponding author \\ from International Society on Brain and Behaviour: 3rd International Congress on Brain and Behaviour \\ Thessaloniki, Greece. 28 November - 2 December 2007 \\ Published: 17 April 2008 \\ Annals of General Psychiatry 2008, 7(Suppl I):SI26 doi:I0.II86/I744-859X-7-SI-SI 26
}

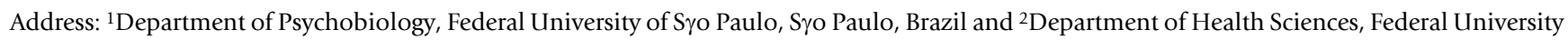

This abstract is available from: http://www.annals-general-psychiatry.com/content/7/SI/SI26

(c) 2008 Brand $\gamma o$ et al.; licensee BioMed Central Ltd.

\section{Background}

Approximately 2,9-9,0 of 1000 infants experience some degree of perinatal ischemic-anoxic or prolonged anoxic insult [1].

\section{Materials and methods}

Seven days old male Swiss mice were distributed on three groups: hypoxia $(\mathrm{H})$, maternal separation (MS) and no handling $(\mathrm{NH})$. H group underwent to $10 \%$ oxygen during 6 hours/day for 6 days and MS group was maintained in normoxia, but separated from their dams such as $\mathrm{H}$ group. When mice completed 3 months old, they were tested on locomotor activity boxes or in plus-maze. The parameters measured were erythrocyte catalase, superoxide dismutase and glutathione peroxidase (GPx) and cerebral catalase. Data were analyzed by one-way ANOVA test and Bonferroni post-hoc test, when appropriated.

\section{Results}

On the activity boxes, during the 5 first minutes, it was observed a significant decrease of vertical movements on $\mathrm{H}$ group, when compared to other groups. However, after 30 minutes, the groups didn't differ. Besides, $\mathrm{H}$ mice demonstrated a diverse emotionality on plus-maze, once the quantity of fecal boli and urine was significant different from group NH. Considering oxidative stress, only GPx values were increased on $\mathrm{H}$ group compared to MS group.

\section{Conclusions}

Neonatal hypoxia is capable of generating long-term alterations on mice behavior and on production and/or activation of some antioxidant enzymes.

\section{References}

I. Tuor UI, Del Bigio MR, Chumas PD: Brain damage due to cerebral hypoxia/ischemia in the neonate: pathology and pharmacological modification. Cerebrovasc Brain Metab Rev 1996, 8(2): $159-193$. 